
under aCC-BY 4.0 International license.

\title{
1 Black pod disease profile: Monitoring its outbreak in
}

\section{Southwest, Nigeria}

$5 \quad{ }^{1}$ Department of Botany, Faculty of Science, University of Ibadan, Ibadan, Nigeria

$6 \quad{ }^{2}$ Cocoa Research Institute of Nigeria (CRIN), Idi-Ayunre, Ibadan, Nigeria

$8 *$ Corresponding Author

$9 \quad$ Email: peterparkers007@gmail.com 


\section{Abstract}

11 Black pod disease (BPD) has been and still remains a major threat to cocoa farmers worldwide

12 due to its annual recurrence, fast spread and highly destructive nature. The disease has caused

13 great anxiety in many cocoa producing communities due to the inability of indigenous cocoa

14 farmers to determine when and where BPD outbreak will take place. Twelve (12) stations were

15 structured from four important cocoa-producing States in the Southwestern region of Nigeria. An

16 investigation of BPD outbreak was conducted in 2015/2016 within these regions. Infected cocoa

17 pods and topsoil samples were collected for laboratory analysis. Pests attack, cherelle wilt and

18 BPD outbreak were seasonal with $50 \%$ chances of occurrence in all the stations. Black pod

19 diseases outbreak was recorded in all the States (100\%) during the rainy season. The disease was

20 at its peak in August 2015 in almost all the stations (station $1(30.0 \%)$, station 3 (23.0\%), station

$2111(16.0 \%)$, station $4(9.0 \%)$, station $5(7.0 \%)$, and station $8(3.0 \%)$. The height of disease

22 severity was in September 2015 (station 1 (100.0\%), station 3 (96.7\%), station 5 (85.7\%), station

$2311(84.3 \%)$, and station $4(70.0 \%)$, with station 8 reaching the $100 \%$ mark in October 2015. Most

24 cocoa farmlands are now being abandoned, unless concerted efforts are made to effectively

25 manage the disease, BPD will greatly reduce cocoa production in Nigeria and around the world.

26 Keywords: Black pod disease outbreak, indigenous cocoa farmers, Cherelle wilt, Pests, Seasonal 


\section{Introduction}

29 Theobroma cacao Linn. (Cocoa) is an evergreen and relatively common understory tree growing

$304-8 \mathrm{~m}$ tall. Cocoa is native to the deep tropical region of South America, and is now widely

31 cultivated in Africa and some parts of Europe, Asia and Australia. Cocoa cultivation has been a

32 major source of income for most third world countries. The largest proportion of global cocoa

33 beans (59\%) comes from West Africa, with Côte d'Ivoire and Ghana producing 1,472,313

34858,720 tonnes respectively in 2016 [1]. Unlike many exotic crops, Cocoa is highly susceptible

35 to pestilence [2]. These pestilences occur seasonally and as such are influenced by weather, they

36 mostly affect coupons, cherelles, unripe and ripe cocoa pods at different developmental stages in

37 the field [3].

38 The earliest account of cocoa pestilence in Africa was reported by Thorold [4]. The topmost

39 invasive diseases of cocoa are black pod disease, swollen shoot, witches' broom, Monilia pod rot,

40 and vascular-streak dieback [3]. Black pod disease has been the most recurrent, highly

41 destructive, dreaded and widespread among other diseases [3]. This disease however seems more

42 established in West Africa than in other cocoa-growing regions around the world. In Nigeria,

43 Cameroon and Togo, black pod disease constitutes the greatest set-back to cocoa production with

44 losses of up to $90 \%$ [3]. In the early 1980s, black pod disease in Ghana was only known to be

45 caused by P. Palmivora. However, in 1985, a severe outbreak, which appeared different from

46 that previously known, was reported in the Akomadan area of the Ashanti region. Laboratory

47 investigations by Dakwa [5] on diseased cocoa pod samples showed that P. megakarya was the

48 causal agent, and this was subsequently confirmed by several researchers [6,7]. This was the first

49 reported incidence of the species in Ghana, but earlier observations and research activities

50 carried out in the Volta region indicated that the species might have existed there, perhaps as far

51 back as the early 1970s. Phytophthora megakarya had been reported in many other African 
53 production before 1985, [3].

54 The occurrence of P. megakarya in West Africa has changed the status of black pod disease in

55 Ghana, Nigeria, Cameroun and other regions involved in cocoa production. Black pod disease

56 has been attributed to several species of Phytophthora such as P. drechsleri [8], P. botryosa [9],

57 P. heveae [10], P. meadii [11], P. capsici [12], P. megakarya [13], P. citrophthora [14], P.

58 katsurae [15] and P. tropicalis [16]. Black pod disease caused by P. megakarya continues to be

59 the major threat to cocoa production in West Africa [3,6]. Virulence in P. megakarya emanates from

60 the ability to produce large number of spores on the pod surface [17].

61 P. megakarya produces lesions of black pod disease with irregular edges on the pod surface

62 whereas lesions caused by P. palmivora have regular borders and are generally smaller [18]. The

63 first symptom is a brown to black spot on the pod, which spreads rapidly in all directions and

64 eventually covers the whole pod. The beans become infected internally about 15 days after the

65 initial infection and are soon of no commercial value [19]. Generally, pods closest to the ground

66 are first infected, with the disease rapidly spreading to affect fruit on the entire tree.

67 Phytophthora megakarya can also cause seedling blight and trunk cankers [20]

68 The disease now poses a serious threat to the cocoa industry and has caused great anxiety and

69 concern in many cocoa producing communities. Pod losses to P. megakarya are massive and

70 some farmers in the affected areas have had virtually no crop for many seasons. As a result of the

71 disease, cocoa farms are being neglected or totally abandonedand some farmers seemingly have

72 little or no enthusiasm in establishing new cocoa farms in the areas where the percentage of

73 black pod disease occurrence is very high [3]. In addition, most farm concierges have turned

74 their attention to other crops due to the incessant black pod disease infestation on cocoa crop.

75 Reports from indigenous cocoa farmers and extension workers as well as reports from the field 
76 during black pod surveys indicate that P. megakarya proliferates faster and it has spread to some

77 important cocoa-growing areas leading to an upsurge of the disease. The disease is not only

78 responsible for immense pod losses, but also infliction of severe stem canker resulting in the

79 death of many cocoa trees [7].

80 The success rate achieved by both biological and chemical control measures is fast declining due

81 to the high level of adaptation of the pathogen to harsh conditions, the constant change in rainfall

82 pattern and irregular fluctuation of other weather parameters coupled with the drastic increase in

83 vulnerability of cocoa plants. The dearth of information on the ontogeny and phylogenetic trend

84 of the species of Phytophthora involved in the recurrent annual perpetuation of black pod disease

85 in cocoa producing areas within the rural and sub-urban communities in Nigeria is a major

86 setback to the effective management of the disease in Nigeria. Hence, there is an urgent need for

87 a revolutionized approach in the management of black pod disease. Unless concerted efforts are

88 made to effectively manage the disease BPD will greatly reduce cocoa production in Nigeria and

89 around the world [3,21]. Therefore, this study was designed to develop a system for black pod

90 disease prediction in order to provide useful and timely information on black pod disease

91 occurrence, its severity and the specific areas expected to be affected. This will minimize

92 fungicide misuse, increase cocoa productivity, reduce the risk of chemical poisoning, increase

93 farmers' profit, foreign exchange and internally generated revenue, and ensure the availability of

94 disease-free and non-toxic raw materials for cocoa processing industries. Lastly, it will create a

95 clean and healthy environment for the sustenance of all forms of life. 


\section{Materials and methods}

\section{$97 \quad$ Research Locations}

98 Twelve (12) commercial cocoa farms in Southwest, Nigeria were selected for black pod disease

99 assessment (Table 1; S1 Appendix). The criteria for selection were: 1) farm size (The minimum

100 acceptable size was $10,000 \mathrm{~m}^{2}$ ), 2) consistency in cocoa production, 3) cropping system and 4)

101 locality. These were used to determine the suitability of the selected cocoa farms in line with the

102 aim of the current research. The selected locations were classed as stations for ease of

103 identification (Figs 1 - 2).

104 Table 1: Location of sampled stations and size of farms surveyed.

\begin{tabular}{llllll}
\hline Station & Location & Latitude $\mathrm{N}$ & Longitude E & Altitude $(\mathrm{m})$ & Size $\left(\mathrm{m}^{2}\right)$ \\
\hline 1 & Òwenà & $7^{\circ} 12^{\prime} 11.52^{\prime \prime}$ & $5^{\circ} 00^{\prime} 55.76^{\prime \prime}$ & 289 & 10,000 \\
2 & Òwenà & $7^{\circ} 12^{\prime} 11.50^{\prime \prime}$ & $5^{\circ} 00^{\prime} 55.76^{\prime \prime}$ & 291 & 10,000 \\
3 & Wáàsimi & $7^{\circ} 10^{\prime} 42.78^{\prime \prime}$ & $4^{\circ} 59^{\prime \prime} 31.34^{\prime \prime}$ & 249 & 30,000 \\
4 & Adaàgbà & $7^{\circ} 22^{\prime} 13.80^{\prime \prime}$ & $4^{\circ} 33^{\prime} 34.42^{\prime \prime}$ & 262 & 40,000 \\
5 & Iyánfowórogi & $7^{\circ} 21^{\prime} 55.22^{\prime \prime}$ & $4^{\circ} 34^{\prime} 16.54^{\prime \prime}$ & 259 & 20,000 \\
6 & Owódé-Igàngán & $7^{\circ} 29^{\prime} 59.99^{\prime \prime}$ & $4^{\circ} 48^{\prime} 59.99^{\prime \prime}$ & 276 & 50,000 \\
7 & Owódé-Igàngán & $7^{\circ} 29^{\prime} 53.45^{\prime \prime}$ & $4^{\circ} 48^{\prime} 59.01^{\prime \prime}$ & 282 & 50,000 \\
8 & Qbáfémi-Owódé & $7^{\circ} 08^{\prime} 30.37^{\prime \prime}$ & $3^{\circ} 25^{\prime} 56.71^{\prime \prime}$ & 187 & 10,000 \\
9 & Qbáfémi-Owódé & $7^{\circ} 08^{\prime} 30.32^{\prime}$ & $3^{\circ} 25^{\prime} 56.73^{\prime \prime}$ & 192 & 10,000 \\
10 & Mòyè & $7^{\circ} 18^{\prime} 54.54^{\prime \prime}$ & $4^{\circ} 01^{\prime} 09.34^{\prime \prime}$ & 205 & 20,000 \\
11 & Qmi-Adió & $7^{\circ} 20^{\prime} 47.58^{\prime \prime}$ & $3^{\circ} 44^{\prime} 30.59^{\prime \prime}$ & 174 & 20,000 \\
12 & Olórò & $7^{\circ} 20^{\prime} 44.00^{\prime \prime}$ & $3^{\circ} 59^{\prime} 34.00^{\prime \prime}$ & 179 & 10,000 \\
\hline
\end{tabular}

105 
107 Black pod disease assessment was conducted for thirteen (13) consecutive months. The period of

108 the disease assessment covered the major cocoa growing season (March to October), the minor

109 cocoa production season (November to April) and the optimum cocoa growing season (July to

110 August) for cocoa production in Nigeria. The minimum Cocoa farm size considered for the

111 assessment of black pod disease incidence and severity was ten thousand square meters $(10,000$

$\left.112 \mathrm{~m}^{2}\right)$ or one hectare (1 hectare).

113 The disease assessment was conducted both in the rainy season and dry season to determine the

114 level of variation of black pod disease outbreak and severity brought about by seasonal changes.

115 Also, the altitude of the study areas was considered in other to determine its influence on disease

116 development and spread. Therefore, the study locations were classed accordingly and the

117 observations made were grouped based on the established criterion.

\section{Black Pod Disease Occurrence}

119 The method adapted for black pod disease incidence determination was that of Luo [22]. Cocoa

120 trees were assessed in a transverse and diagonal mode as described in Fig 2 and Plate 4 within

121 each study location. Green and ripe Cocoa pods from each tree were inspected for the symptoms

122 of black pod disease; the rain splash zone described in Plate 5 was of interest. If an infected pod

123 was detected on the tree, the stand (tree) was noted as being infected. The assessment was

124 repeated for a total of one hundred (100) trees and the observations noted. Each tree stand was

125 noted as disease free (Healthy) or Infected based on the presence or absence of black pod disease

126 symptoms. The observations were carried out for thirteen (13) months (May, 2015 to May,

127 2016).

128

$$
\text { Black Pod Disease Occurrence }=\frac{\text { Number of infected trees }}{\text { Total number of trees }} \times 100
$$




\section{Black Pod Disease Severity}

131 For the determination of black pod disease severity, Cocoa trees were also assessed in a

132 transverse and diagonal mode as shown in S1 Fig [23]. Two methods were adapted for black pod

133 disease severity determination to minimize error(s). The first method involves the measurement

134 of infected cocoa pods and the percentage infection calculated based on the total Cocoa pod

135 length basically from the rain splash zone (Fig 3). The second method involves the superficial

136 assessment of the extent of damage inflicted by the disease on each infected cocoa pod and a

137 score from 0 to 5 ascribed (Table 2) [24]. This scored served as the rating for the disease

138 infection for that particular cocoa pod.

$$
\begin{aligned}
& \text { Black Pod Disease Severity }=\frac{\text { Length of Black Pod Infected Region on the Pod }}{\text { Length of Cocoa pod }} \\
& \quad \times 100
\end{aligned}
$$

\section{$140 \quad$ Fig 3: The mode of biological data collection on the field}

141 In general, the observations made within each Season, Station Altitude, State and the Southwest in general were calculated using the following formulae:

143 Observations recorded per Season: \% $\mathrm{SI}=\left(\mathrm{SOS}_{\mathrm{i}} / \mathrm{SL}_{\text {total }}\right)$

144 Where SI = Seasonal Influence on BPD Status, $\mathrm{SOS}_{\mathrm{i}}=$ Sum of all observations made per Season

145 (per month) and $\mathrm{SL}_{\text {total }}=$ The Total No. of study locations assessed

146 Observations recorded per Altitude level: $\% \mathrm{AI}=\left(\mathrm{SOA}_{\mathrm{i}} / \mathrm{SL}_{\text {total }}\right)$

147 Where $\mathrm{AI}=$ Altitudinal influence on BPD Status, $\mathrm{SOA}_{\mathrm{i}}=\mathrm{Sum}$ of all observations made per

148 altitudinal Level (per month) and $\mathrm{SL}_{\text {total }}=$ The Total No. of study locations assessed 
150 Where BSS = BPD Status in Southwest, Nigeria, $\mathrm{SO}_{\mathrm{i}}=\mathrm{Sum}$ of all observations (per month)

151 from the stations and $\mathrm{SL}_{\text {total }}=$ The Total No. of study locations assessed

152 For BPD Status in States: $\% \mathrm{BST}=\left(\mathrm{ST}_{\mathrm{i}} / \mathrm{SL}_{\text {total }}\right)$

153 Where BST $=$ BPD Status in each State, $\mathrm{SOS}_{\mathrm{i}}=$ the sum of BPD Status from all the sampled

154 stations within a State (per month) and $\mathrm{SL}_{\text {total }}=$ The Total No. of study locations assessed

Fig 1: The geographical locations of the selected cocoa farm stations in Soutwest Nigeria.

Fig 2: The severity intensity of black pod disease in Nigeria (2015/2016)

Table 2: Black pod disease severity status determination

\begin{tabular}{llll}
\hline & $\begin{array}{l}\text { BPD INFECTION } \\
\text { Severity) }\end{array}$ & per COCOA POD (BPD & \\
\hline Score & Infected Portion & Percentage Infection & Inference \\
0 & None & $0 \%$ & Healthy \\
1 & $(1 / 5)$ & $20 \%$ & Not Severe \\
2 & $(2 / 5)$ & $40 \%$ & Mildly Severe \\
3 & $(3 / 5)$ & $60 \%$ & Averagely \\
& & & Severe \\
4 & $(4 / 5)$ & $80 \%$ & Severe \\
5 & All & $100 \%$ & Extremely \\
& & & Severe \\
\hline
\end{tabular}




\section{Previous black pod disease records}

163 The previous disease record on the prevalence and intensity of black pod disease of cocoa was

164 obtained from Cocoa Research Institute of Nigeria (CRIN), Idi-Ayunre, Ibadan, Oyo State,

165 Nigeria and the report of Lawal and Emaku [23]. The data collected spanned from 1985 to 2014.

\section{Data Analysis}

167 Data were collected from the rain splash zone, root rhizosphere and husk dumpsite as shown in

168 Fig 3. Qualitative data were represented as charts and graphs plotted using Microsoft Office

169 (Excel) 2007 service pack and SPSS version 20.0 for 32 bits resolution. An Analysis of variance 170 was carried out using COSTAT 9.0 software, while the homogeneity of means was determined 171 using Duncan Multiple Range Test (DMRT).

\section{Results}

\section{Orientation on PDA (Morphological Characters)}

174 The pathogen appeared cotton white on potato dextrose agar (PDA) from day one. A single

175 cluster of the velvet mycelia colony was formed around the Petri-plate. The silky mycelia colony

176 turned pale creamy-yellow in older cultures due to the production of light lemon-yellowish

177 secretion which could be a secondary metabolite or an extracellular secreted enzyme (no further

178 test was conducted to determine the nature of the metabolite secreted) around the midpoint of 179 inoculation as shown in Fig 4a

\section{Microscopy (Cytological Characters)}

181 The type of spore(s) produced i.e. chlamydospores (Zoospores), Oospores (Sexual spores) or 182 aplanospores was the distinguishing factor within the various species of Phytophthora notable 183 for inciting black pod disease. Micro-images of the hyphal structure appeared hyaline, septate 
184 and heterogeneously branched, double walled with thin layers. The production of zoospores on

185 special reproductive hyphae known as the sporangiophore was also noticed. The zoospores

186 produced were double layered, ellipsoidal/oval in shape, with a pointed node each for attachment

187 to the sporangiophore. Each zoospore had a single flagellum that facilitated mobility. The

188 flagellum was short and located at the posterior part of the spore. The spore stained purple to

189 violet when exposed to lactophenol in cotton blue dye and were categorically attached singly at

190 the apices of the sporangiophore (Fig 4b).

191 Fig 4: The morphological and cytological features of Phytophthora megakarya on potato

192 dextrose agar (PDA) and under the microscope

\section{The life cycle of Phytophthora megakarya}

194 The life cycle of $P$. megakarya was studied in the Mycology/Pathology Laboratory of the

195 Department of Botany, University of Ibadan (Fig 5). Spores of the pathogen germinated into

196 motile zoospores (Fig 5b). The motile spores lose their flagella, germinate, and produce infection

197 peg alongside penetration mechanisms in order to gain access into the host tissue (Fig 5c). After

198 germination, the pathogen produces somatic cell structures, mycelia and hyphal structures (Fig

199 5d). At maturity, the pathogen produces fruiting structures (sporangiophores) with spores

200 apically located at the end of the hyphae (Fig 5e). Sporangiophores of Phytophthora megakarya

201 are branched reproductive hyphae with thick walls. The sporangiophore bears spores that are

202 attached to it by the peduncle (Fig 5e). Mature flagellated zoospores are then released into the

203 environment when there is distress or limitation in food supply (Fig 5a).

204 The dispersed spores either swim towards nearby hosts based on the chemical attraction or 205 signalling from the root rhizosphere or form thick enclosures that protect them from desiccation 
206 and other adverse environmental conditions. Spore dispersion is often aided by rain splash or

207 insect activities (Fig 5). Pod infection start from cocoa pod closest to the soil and it is further

208 disseminated by the activities of insects and other rodents within the cocoa field (Fig 5).

209 Fig 5: The life cycle of Phytophthora megakarya responsible for inciting black pod disease of

210 cocoa in South western Nigeria.

\section{An overview of the major Diseases/Pestilence of cocoa in South 212 western Nigeria}

213 The statutory disease assessment conducted in Ogun, Ondo, Osun and Oyo States in South

214 western, Nigeria during the 2015/2016 cocoa production season showed that the probability for

215 the period of occurrence of pests (i.e. insect activities, rodents etc.) was $0.5(50 \%)$, with the

216 activities of these pests severely rampant in the dry season. Cherelle wilt was noticed in all the

217 cocoa farms assessed in the dryer periods of the year $0.5(50 \%)$ with no traces during the wet

218 season. It was further observed that black pod disease had the same level of probability in terms

219 of seasonal occurrence $[0.5(50 \%)]$ but the occurrence of black pod disease was majorly

220 prominent in the rainy season (Table 3).

221

222

Table 3: General estimation of the prevalence of diseases and pestilence of cocoa in Southwest, Nigeria

\begin{tabular}{lllll}
\hline Disease & $\begin{array}{l}\text { Annual } \\
\text { Prevalence (\%) }\end{array}$ & $\begin{array}{l}\text { Prob. } \\
\text { Occurrence }\end{array}$ & $\begin{array}{l}\text { Rainy } \\
\text { Season (\%) }\end{array}$ & $\begin{array}{l}\text { Dry } \\
\text { Season } \\
(\%)\end{array}$ \\
\hline $\begin{array}{l}\text { Black } \\
\text { Pod }\end{array}$ & 100 & 0.5 & 100 & 0.0 \\
Cherelle & 100 & 0.5 & 0.0 & 100 \\
\hline
\end{tabular}


Wilt

Pestilence

81.9

0.5

0.0

100

Canker

0.0

0.0

0.0

0.0

223

224

225

226

227

228

229

230

231

232

233

234

235

236

237

238

239

240

241
Statutory disease assessment during the 2015/2016 cocoa production season in Southwest, Nigeria

\section{The Level of Diseases and Pest Invasion in South western Nigeria}

The level of black pod disease epidemics during the wet season was $100 \%$ across all the states.

Cherelle wilt had $100 \%$ occurrence in the dry season but it was not as intensive as black pod disease. Insect and Pest invasion was $81.9 \%$ as it was undetected in some of the cocoa farms assessed (Table 3). There were no observable symptoms of stem canker in all the cocoa farms assessed from the far end of Ondo State to the rural communities in Ogun State. Therefore, the possibility of occurrence of stem canker within these regions was $0 \%$ and as such, one less problem for local cocoa farmers to contend with (Table 3).

\section{Black pod disease outbreak in the sampled Stations}

Black pod disease (BPD) was noticed early in Stations 5 and 6 with 3.0 and $9.0 \%$ level of epidemics respectively for May 2015 (Table 4). There were no visible signs or symptoms of the disease in other Stations (0.0\% BPD incidence). In June 2015, Station 3 had the highest recorded BPD occurrence (12.0\%), Station 5 was second on the disease profile list with BPD outbreak of 11.0\%. Stations 1, 2 and 4 had slightly severe epidemics (8.0, 7.0 and 7.0\% respectively). Other Stations had NO epidemics $(0.0 \%)$ as shown in Fig 6.

Fig 6: Black pod disease incidence across Southwest, Nigeria for the $2015 / 2016$ cocoa production season 
242 There was decline in BPD epidemics in September 2015, Station 4 took the lead $(16.0 \%)$,

243 followed by Station 8 with $15.0 \%$ BPD epidemics. Stations 11, 3, 1, and 5 had slightly severe to

244 mild BPD outbreak of 14.0, 12.0, 10.0, and 7.0\% respectively. Further decline in disease

245 outbreak was noted in some Stations in the month of October like Station $11(0.0 \%)$, Station 3

246 (4.0\%), Station $1(6.0 \%)$, Station $5(7.0 \%)$ and Station $4(13.0 \%)$ with Station 8 showing

247 progressive increase in black pod diseases occurrence (22.0\%) as shown in Fig 6.

248 There were no observable symptoms or signs associated with BPD outbreak for November and

249 December 2015, likewise January, February, March, April and May 2016 (Table 4). This was

250 partly due to the fact that most cocoa farmers have harvested their pods from the field coupled

251 with the fact that there was no available moisture within the soil surface to effect Phytophthora

252 spore germination and dispersion. 
Table 4: Profile of black pod disease outbreak within the sampled stations

\section{Average Monthly Disease Occurrence (\%)}

\begin{tabular}{|c|c|c|c|c|c|c|c|c|c|c|c|c|}
\hline Period & Òwenà & Òwenà-2 & Wáàsimi & Adaàgbà & Iyánfowórogi & O-Igàngán & Owódé & Q-Owódé & Q-Owódé & Mòyè & D-Lógbà & Olórò \\
\hline May 2015 & $0.0^{\mathrm{c}}$ & $0.0^{\mathrm{c}}$ & $0.0^{\mathrm{c}}$ & $0.0^{\mathrm{c}}$ & $3.0^{\mathrm{b}}$ & $9.0^{\mathrm{a}}$ & $0.0^{\mathrm{c}}$ & $0.0^{\mathrm{c}}$ & $0.0^{\mathrm{c}}$ & $0.0^{\mathrm{c}}$ & - & - \\
\hline June 2015 & $7.0^{\mathrm{b}}$ & $8.0^{\mathrm{b}}$ & $12.0^{\mathrm{a}}$ & $7.0^{\mathrm{b}}$ & $11.0^{\mathrm{a}}$ & - & - & $0.0^{\mathrm{c}}$ & $0.0^{\mathrm{c}}$ & - & - & - \\
\hline July 2015 & $20.0^{\mathrm{a}}$ & - & $16.0^{\mathrm{b}}$ & $12.0^{\mathrm{c}}$ & $15.0^{\mathrm{b}}$ & - & - & $0.0^{\mathrm{e}}$ & $0.0^{\mathrm{e}}$ & - & $6.0^{\mathrm{d}}$ & - \\
\hline Aug.2015 & $30.0^{\mathrm{a}}$ & - & $23.0^{\mathrm{b}}$ & $9.0^{\mathrm{d}}$ & $7.0^{\mathrm{d}}$ & - & - & - & $3.0^{\mathrm{e}}$ & - & $16.0^{\mathrm{c}}$ & - \\
\hline Sept.2015 & $10.0^{c}$ & - & $12.0^{\mathrm{bc}}$ & $16.0^{\mathrm{a}}$ & $7.0^{\mathrm{d}}$ & - & - & - & $15.0^{\mathrm{a}}$ & - & $14.0^{\mathrm{ab}}$ & - \\
\hline Oct. 2015 & $6.0^{\mathrm{c}}$ & $0.0^{\mathrm{e}}$ & $4.0^{\mathrm{d}}$ & $13.0^{\mathrm{b}}$ & $7.0^{\mathrm{c}}$ & $0.0^{\mathrm{e}}$ & - & - & $22.0^{\mathrm{a}}$ & $0.0^{\mathrm{e}}$ & $0.0^{\mathrm{e}}$ & $0.0^{\mathrm{e}}$ \\
\hline Nov.2015 & $0.0^{\mathrm{a}}$ & $0.0^{\mathrm{a}}$ & $0.0^{\mathrm{a}}$ & $0.0^{\mathrm{a}}$ & $0.0^{\mathrm{a}}$ & $0.0^{\mathrm{a}}$ & - & - & $0.0^{\mathrm{a}}$ & $0.0^{\mathrm{a}}$ & $0.0^{\mathrm{a}}$ & $0.0^{\mathrm{a}}$ \\
\hline Dec. 2015 & $0.0^{\mathrm{a}}$ & $0.0^{\mathrm{a}}$ & $0.0^{\mathrm{a}}$ & $0.0^{\mathrm{a}}$ & $0.0^{\mathrm{a}}$ & $0.0^{\mathrm{a}}$ & - & - & $0.0^{\mathrm{a}}$ & $0.0^{\mathrm{a}}$ & $0.0^{\mathrm{a}}$ & $0.0^{\mathrm{a}}$ \\
\hline Jan. 2016 & $0.0^{\mathrm{a}}$ & $0.0^{\mathrm{a}}$ & $0.0^{\mathrm{a}}$ & $0.0^{\mathrm{a}}$ & $0.0^{\mathrm{a}}$ & $0.0^{\mathrm{a}}$ & - & - & $0.0^{\mathrm{a}}$ & $0.0^{\mathrm{a}}$ & $0.0^{\mathrm{a}}$ & $0.0^{\mathrm{a}}$ \\
\hline Feb.2016 & $0.0^{\mathrm{a}}$ & $0.0^{\mathrm{a}}$ & $0.0^{\mathrm{a}}$ & $0.0^{\mathrm{a}}$ & $0.0^{\mathrm{a}}$ & $0.0^{\mathrm{a}}$ & - & - & $0.0^{\mathrm{a}}$ & $0.0^{\mathrm{a}}$ & $0.0^{\mathrm{a}}$ & $0.0^{\mathrm{a}}$ \\
\hline Mar.2016 & $0.0^{\mathrm{a}}$ & $0.0^{\mathrm{a}}$ & $0.0^{\mathrm{a}}$ & $0.0^{\mathrm{a}}$ & $0.0^{\mathrm{a}}$ & $0.0^{\mathrm{a}}$ & - & - & $0.0^{\mathrm{a}}$ & $0.0^{\mathrm{a}}$ & $0.0^{\mathrm{a}}$ & $0.0^{\mathrm{a}}$ \\
\hline Apr.2016 & $0.0^{\mathrm{a}}$ & $0.0^{\mathrm{a}}$ & $0.0^{\mathrm{a}}$ & $0.0^{\mathrm{a}}$ & $0.0^{\mathrm{a}}$ & $0.0^{\mathrm{a}}$ & - & - & $0.0^{\mathrm{a}}$ & $0.0^{\mathrm{a}}$ & $0.0^{\mathrm{a}}$ & $0.0^{\mathrm{a}}$ \\
\hline May 2016 & $0.0^{\mathrm{a}}$ & $0.0^{\mathrm{a}}$ & $0.0^{\mathrm{a}}$ & $0.0^{\mathrm{a}}$ & $0.0^{\mathrm{a}}$ & $0.0^{\mathrm{a}}$ & - & - & $0.0^{\mathrm{a}}$ & $0.0^{\mathrm{a}}$ & $0.0^{\mathrm{a}}$ & $0.0^{\mathrm{a}}$ \\
\hline
\end{tabular}

260 Means with the same alphabets across the row are not significantly different at $\mathrm{P}<0.05$ using Duncan Multiple Range Test (DMRT) for

261 separation of statistically significant means. Data collected were represented as "Means" only

262 O-Igàngán : Owódé-Igàngán, Q-Owódé : Qbafèmi-Owódé, D-Lógbà: Dáagi-Lógbà 


\section{Black pod disease outbreak in Ondo, Ogun, Osun and Oyo States}

266 Black pod disease outbreak was recorded early in Osun State (1.5\%) in May 2015, other States

267 had NO BPD incidence (0.0\%). Ondo and Osun States experienced slight BPD outbreak (9.5 and

2689.0 , respectively) in the month of June 2015. There was a progressive disease increase in Ondo

269 State (18.0\%) and Osun State (13.5\%) for the month of July, 2015. Ogun and Oyo States had NO

270 known cases of BPD outbreak for these months (Table 5).

271 Ondo State maintained top position in BPD outbreak (26.5\%) for August 2015, closed followed

272 by Oyo State (16.0\%). Osun State and Ogun State had 8.0\% and 3.0\% respectively. An increase

273 in BPD outbreak was experienced in Ogun State from the month of September (15.0\%) through

274 October $(22.0 \%)$ in 2015, whereas Osun, Ondo and Oyo State experienced decline in BPD

275 outbreak from 11.5 to $10.0 \%, 11.0$ to $5.0 \%$, and 14.0 and $0.0 \%$, respectively (Table 5). There

276 was no incidence of black pod disease prevalence in the dry season for these States. 
282 Table 5: Monthly black pod disease assessment in four states within Southwest Nigeria

\begin{tabular}{|c|c|c|c|c|}
\hline & \multicolumn{4}{|c|}{ Monthly Regional Disease Occurrence (\%) per 100 trees } \\
\hline & Ondo & Osun & Ogun & Оуо \\
\hline May 2015 & $0.0^{\mathrm{b}}$ & $1.5^{\mathrm{a}}$ & $0.0^{\mathrm{b}}$ & $0.0^{\mathrm{b}}$ \\
\hline June 2015 & $9.5^{\mathrm{a}}$ & $9.0^{\mathrm{a}}$ & $0.0^{\mathrm{b}}$ & $0.0^{\mathrm{b}}$ \\
\hline July 2015 & $18.0^{\mathrm{a}}$ & $13.5^{\mathrm{b}}$ & $0.0^{\mathrm{d}}$ & $6.0^{\mathrm{c}}$ \\
\hline Aug.2015 & $26.5^{\mathrm{a}}$ & $8.0^{\mathrm{c}}$ & $3.0^{\mathrm{d}}$ & $16.0^{\mathrm{b}}$ \\
\hline Sept.2015 & $11.0^{\mathrm{a}}$ & $11.5^{\mathrm{a}}$ & $15.0^{\mathrm{a}}$ & $14.0^{\mathrm{a}}$ \\
\hline Oct. 2015 & $5.0^{\mathrm{c}}$ & $10.0^{\mathrm{b}}$ & $22.0^{\mathrm{a}}$ & $0.0^{\mathrm{d}}$ \\
\hline Nov.2015 & $0.0^{\mathrm{a}}$ & $0.0^{\mathrm{a}}$ & $0.0^{\mathrm{a}}$ & $0.0^{\mathrm{a}}$ \\
\hline Dec. 2015 & $0.0^{\mathrm{a}}$ & $0.0^{\mathrm{a}}$ & $0.0^{\mathrm{a}}$ & $0.0^{\mathrm{a}}$ \\
\hline Jan. 2016 & $0.0^{\mathrm{a}}$ & $0.0^{\mathrm{a}}$ & $0.0^{\mathrm{a}}$ & $0.0^{\mathrm{a}}$ \\
\hline Feb.2016 & $0.0^{\mathrm{a}}$ & $0.0^{\mathrm{a}}$ & $0.0^{\mathrm{a}}$ & $0.0^{\mathrm{a}}$ \\
\hline Mar.2016 & $0.0^{\mathrm{a}}$ & $0.0^{\mathrm{a}}$ & $0.0^{\mathrm{a}}$ & $0.0^{\mathrm{a}}$ \\
\hline Apr.2016 & $0.0^{\mathrm{a}}$ & $0.0^{\mathrm{a}}$ & $0.0^{\mathrm{a}}$ & $0.0^{\mathrm{a}}$ \\
\hline May 2016 & $0.0^{\mathrm{a}}$ & $0.0^{\mathrm{a}}$ & $0.0^{\mathrm{a}}$ & $0.0^{\mathrm{a}}$ \\
\hline
\end{tabular}

283 Means with the same alphabets across the row are not significantly different at $\mathrm{P}<0.05$ using Duncan 284 Multiple Range Test (DMRT) for separation of statistically significant means. Data collected were 285 represented as "Means" only

\section{Farm altitude and black pod disease Outbreak}

288 Cocoa farms located above 200m from sea level $(>200 \mathrm{~m})$ experienced early BPD outbreak, 289 beginning from May (0.8\%) through August (17.3\%) 2015 followed by a sharp decline from the 290 month of September (11.3\%) through October (7.5\%) and 0\% black pod disease incidence within 
291 the dryer period of the season. This result was an Indication of the importance of altitude in black

292 pod disease development (Table 6).

293 Cocoa farmlands located in regions that are below $200 \mathrm{~m}$ above sea level $(\leq 200 \mathrm{~m})$ had a slow

294 start to black pod disease development (Table 6) with the peak level of black pod disease

295 prevalence in September $2015(14.5 \%)$ and an abrupt decline in October (11.0\%) in 2015

296 through May 2016. A cross comparison between the two altitudes suggest that the activities of

297 the pathogen was closely affected by the altitude of the cocoa farmlands, whereas the mode of

298 spread was a function of the topography of the environment. 
309 Table 6: Different Altitude levels of the sampled stations and its effects on black pod disease

310 outbreak

\section{Altitude and \%BPD expression per 100trees}

\begin{tabular}{|c|c|c|}
\hline Period & $100 m-200 m$ & $201 m-300 m$ \\
\hline May, 2015 & $0.0^{\mathrm{b}}$ & $0.8^{\mathrm{a}}$ \\
\hline June, 2015 & $0.0^{\mathrm{b}}$ & $9.3^{\mathrm{a}}$ \\
\hline July, 2015 & $3.0^{\mathrm{b}}$ & $15.8^{\mathrm{a}}$ \\
\hline Aug., 2015 & $9.5^{\mathrm{b}}$ & $17.3^{\mathrm{a}}$ \\
\hline Sept., 2015 & $14.5^{\mathrm{a}}$ & $11.3^{b}$ \\
\hline Oct., 2015 & $11.0^{\mathrm{a}}$ & $7.5^{\mathrm{b}}$ \\
\hline Nov., 2015 & $0.0^{\mathrm{a}}$ & $0.0^{\mathrm{a}}$ \\
\hline Dec., 2015 & $0.0^{\mathrm{a}}$ & $0.0^{\mathrm{a}}$ \\
\hline Jan., 2016 & $0.0^{\mathrm{a}}$ & $0.0^{\mathrm{a}}$ \\
\hline Feb., 2016 & $0.0^{\mathrm{a}}$ & $0.0^{\mathrm{a}}$ \\
\hline Mar., 2016 & $0.0^{\mathrm{a}}$ & $0.0^{\mathrm{a}}$ \\
\hline April, 2016 & $0.0^{\mathrm{a}}$ & $0.0^{\mathrm{a}}$ \\
\hline May, 2016 & $0.0^{\mathrm{a}}$ & $0.0^{\mathrm{a}}$ \\
\hline
\end{tabular}

311 Means with the same alphabets across the row are not significantly different at $\mathrm{P}<0.05$ using

312 Duncan Multiple Range Test (DMRT) for separation of statistically significant means. Data

313 collected were represented as "Means" only 


\section{Black pod disease prevalence and Severity in South western Nigeria}

316 The average disease occurrence within the Southwest for the month of May 2015 was $0.4 \%$.

317 Further records taken for the preceding months are as follow; June 2015 (4.6\%), July 2015

318 (9.4\%), and August 2015 was the peak of disease occurrence within this terrain with an average

319 value of $13.4 \%$ (per one hundred cocoa trees sampled). A decline in disease value was observed

320 in the month of September 2015, with an average value of $12.9 \%$. Further decline in value

321 occurred in October $2015(9.3 \%)$ prior to harvesting of cocoa pods by farmers. The months of

322 November, December 2015, January, February, March, April and May 2016 had negligible and

323 unsubstantial amount of disease prevalence (Table 7). The same trend of disease report was

324 observed within this zone for the disease severity. The peak of disease intensity was recorded in

325 September 2015 with a mean value of $86.8 \%$, while the least recorded occurrences were in the

326 months of November, December 2015, January, February, March, April and May 2016 with

$327 \quad 0.0 \%$ disease intensity (Table 7 ).

328

329

330

331

332

333

334 
335 Table 7: Black pod disease profile from May 2015 to May 2016 in Southwest, Nigeria

\section{Black Pod Disease in Southwest Nigeria}

\section{Period}

May, 2015

June, 2015

July, 2015

Aug., 2015

Sept., 2015

Oct., 2015

Nov., 2015

Dec., 2015

Jan., 2016

Feb., 2016

Mar., 2016

April, 2016

May, 2016
Avg. Occurrence (\%)

$0.4^{\mathrm{d}}$

$4.6^{\mathrm{c}}$

$9.4^{\mathrm{b}}$

$13.4^{\mathrm{a}}$

$12.9^{\mathrm{a}}$

$9.3^{\mathrm{b}}$

$0.0^{\mathrm{d}}$

$0.0^{\mathrm{d}}$

$0.0^{\mathrm{d}}$

$0.0^{\mathrm{d}}$

$0.0^{\mathrm{d}}$

$0.0^{\mathrm{d}}$

$0.0^{\mathrm{d}}$
Avg. Severity (\%)

$10.0^{\mathrm{f}}$

$56.6^{c}$

$55.2^{\mathrm{d}}$

$79.8^{b}$

$86.8^{\mathrm{a}}$

$49.3^{\mathrm{e}}$

$0.0^{\mathrm{g}}$

$0.0^{\mathrm{g}}$

$0.0^{\mathrm{g}}$

$0.0^{\mathrm{g}}$

$0.0^{\mathrm{g}}$

$0.0^{\mathrm{g}}$

$0.0^{\mathrm{g}}$

336 Means with the same alphabets down the column are not significantly different at $\mathrm{P}<0.05$ using

337 Duncan Multiple Range Test (DMRT) for separation of statistically significant means. Data

338 collected were represented as "Means" only 


\section{Black pod disease profile in Ogun, Ondo, Osun and Oyo States \\ 346 (Southwest, Nigeria)}

347 The general field assessment conducted in 2015/2016 showed that Ondo State had the highest

348 level of black pod disease prevalence (Incidence) and Osun State had the highest level of disease

349 Intensity (Severity) with average annual values of $8.8 \%$ for BPD outbreak (Ondo) and $53.1 \%$

350 (Osun) for BPD severity (Table 8). The general result for BPD outbreak and prevalence was

351 recorded thus: Ondo State $(8.8 \%, 46.2 \%)$, Osun State $(6.7 \%, 53.1 \%)$, Ogun State $(5.0 \%, 31.7 \%)$,

352 and Oyo State $(4.5 \%, 39.3 \%)$ as reported in Table 8.

353 Table 8: Seasonal Changes and its influence on black pod disease outbreak in some

354 Southwestern States

Occurrence (\%) Severity $(\%)$

\begin{tabular}{lllll} 
State & Rainy Season & Dry Season & Rainy Season & Dry Season \\
\hline Ondo & $8.8^{\mathrm{a}}$ & $0.0^{\mathrm{a}}$ & $46.2^{\mathrm{ab}}$ & $0.0^{\mathrm{a}}$ \\
Osun & $6.7^{\mathrm{b}}$ & $0.0^{\mathrm{a}}$ & $53.1^{\mathrm{a}}$ & $0.0^{\mathrm{a}}$ \\
Ogun & $5.0^{\mathrm{bc}}$ & $0.0^{\mathrm{a}}$ & $31.7^{\mathrm{c}}$ & $0.0^{\mathrm{a}}$ \\
Oyo & $4.5^{\mathrm{c}}$ & & & \\
\end{tabular}

355 Means with the same alphabets down the column are not significantly different at $\mathrm{P}<0.05$ using

356 Duncan Multiple Range Test (DMRT) for separation of statistically significant means. Data

357 collected were represented as "Means" only.

358 The overall annual estimation of BPD intensity and outbreak within Southwest, Nigeria

$359(2015 / 2016)$ was $42.6 \%$ and $6.2 \%$ respectively (Table 9$)$. 
360 Table 9: The average black pod disease status in Southwest, Nigeria $(2015 / 2016)$
Black Pod Disease
Rainy Season (\%)
Dry Season (\%)

Occurrence

$6.2^{\mathrm{a}}$

$0.0^{\mathrm{b}}$

Severity

$42.6^{\mathrm{a}}$

$0.0^{\mathrm{b}}$
361

362

363

364

365

366

367

368

369

370

371

372

373

374

375

\section{Black pod disease severity in the sampled Stations}

Black pod disease was expressed early in Stations 5 and $6(60.0 \%$ and $71.1 \%)$. Other Stations had $0.0 \%$ disease expression in the month of May, 2015. The disease severity for June 2015 was 93.9\% for Station 3, 62.5\% for Station 2, 60.0\% for Station 1, 95.1\% for Station 4, and 90.9\% for Station 5. Other Stations had 0.0\% BPD severity within that period (Table 10). Station 1 had the highest black pod disease intensity in the Southwest (87.5\%) in the month of July, closely followed by Station 4 (78.1\%), Station $11(76.7 \%)$, Station $5(62.2 \%)$, and Station $3(60.0 \%)$ respectively.

In August, Station 3 had the highest BPD severity level (93.0\%) in the Southwest of Nigeria, closely followed by Station 1 (92.7\%), Station 5 (89.2\%), Station 4 (80.0\%), Station $11(75.0 \%)$, and Station $8(66.7 \%)$ as documented in Table 12. In September 2015, Station 1 had 100.0\% BPD severity, Station 3 had 96.7\%, Station 8 had $86.7 \%$, Station 5 had $85.7 \%$, Station 11 had 
$37684.3 \%$, and Station was the least with 70.0\%. There was a massive decline in disease outbreak in

377 some locations in the month of October like Station $11(0.0 \%)$, Station $3(55.0 \%)$, Station 1

$378(0.0 \%)$. Stations 4,5 , and 8 still had high BPD severity with the following values $64.6,74.3$ and

$379100.0 \%$, respectively (Table 10). There were no observable symptoms of BPD within in the later

380 periods of the season. 
Average Monthly Disease Severity (\%)

\begin{tabular}{|c|c|c|c|c|c|c|c|c|c|c|c|c|}
\hline Period & Òwenà & Òwenà-2 & Wáàsimi & Adaàgbà & Iyánfowórogi & O-Igàngán & Owódé & Q-Owódé & Q-Owódé & Mòyè & D-Lógbà & Olórò \\
\hline May, 2015 & $0.0^{\mathrm{c}}$ & $0.0^{\mathrm{c}}$ & $0.0^{\mathrm{c}}$ & $0.0^{\mathrm{c}}$ & $60.0^{\mathrm{b}}$ & $71.1^{\mathrm{a}}$ & $0.0^{\mathrm{c}}$ & $0.0^{\mathrm{c}}$ & $0.0^{\mathrm{c}}$ & $0.0^{\mathrm{c}}$ & - & - \\
\hline June, 2015 & $60.0^{\mathrm{b}}$ & $62.5^{\mathrm{b}}$ & $93.3^{\mathrm{a}}$ & $95.1^{\mathrm{a}}$ & $90.9^{a}$ & - & - & $0.0^{\mathrm{c}}$ & $0.0^{\mathrm{c}}$ & - & - & - \\
\hline July, 2015 & $87.5^{\mathrm{a}}$ & - & $60.0^{c}$ & $78.1^{\mathrm{b}}$ & $62.2^{c}$ & - & - & $0.0^{\mathrm{d}}$ & $0.0^{\mathrm{d}}$ & - & $76.7^{\mathrm{b}}$ & - \\
\hline Aug., 2015 & $92.7^{\mathrm{a}}$ & - & $93.0^{\mathrm{a}}$ & $80.0^{c}$ & $89.2^{\mathrm{b}}$ & - & - & - & $66.7^{\mathrm{e}}$ & - & $75.0^{\mathrm{d}}$ & - \\
\hline Sept., 2015 & $100.0^{\mathrm{a}}$ & - & $96.7^{b}$ & $70.0^{\mathrm{e}}$ & $85.7^{\mathrm{c}}$ & - & - & - & $86.7^{\mathrm{c}}$ & - & $84.3^{d}$ & - \\
\hline Nov., 2015 & $0.0^{\mathrm{a}}$ & $0.0^{\mathrm{a}}$ & $0.0^{\mathrm{a}}$ & $0.0^{\mathrm{a}}$ & $0.0^{\mathrm{a}}$ & $0.0^{\mathrm{a}}$ & - & - & $0.0^{\mathrm{a}}$ & $0.0^{\mathrm{a}}$ & $0.0^{\mathrm{a}}$ & 0.0 \\
\hline Dec., 2015 & $0.0^{\mathrm{a}}$ & $0.0^{\mathrm{a}}$ & $0.0^{\mathrm{a}}$ & $0.0^{\mathrm{a}}$ & $0.0^{\mathrm{a}}$ & $0.0^{\mathrm{a}}$ & - & - & $0.0^{\mathrm{a}}$ & $0.0^{\mathrm{a}}$ & $0.0^{\mathrm{a}}$ & 0.0 \\
\hline Jan., 2016 & $0.0^{\mathrm{a}}$ & $0.0^{\mathrm{a}}$ & $0.0^{\mathrm{a}}$ & $0.0^{\mathrm{a}}$ & $0.0^{\mathrm{a}}$ & $0.0^{\mathrm{a}}$ & - & - & $0.0^{\mathrm{a}}$ & $0.0^{\mathrm{a}}$ & $0.0^{\mathrm{a}}$ & 0.0 \\
\hline Feb., 2016 & $0.0^{\mathrm{a}}$ & $0.0^{\mathrm{a}}$ & $0.0^{\mathrm{a}}$ & $0.0^{\mathrm{a}}$ & $0.0^{\mathrm{a}}$ & $0.0^{\mathrm{a}}$ & - & - & $0.0^{\mathrm{a}}$ & $0.0^{\mathrm{a}}$ & $0.0^{\mathrm{a}}$ & 0.0 \\
\hline Mar., 2016 & $0.0^{\mathrm{a}}$ & $0.0^{\mathrm{a}}$ & $0.0^{\mathrm{a}}$ & $0.0^{\mathrm{a}}$ & $0.0^{\mathrm{a}}$ & $0.0^{\mathrm{a}}$ & - & - & $0.0^{\mathrm{a}}$ & $0.0^{\mathrm{a}}$ & $0.0^{\mathrm{a}}$ & 0.0 \\
\hline May, 2016 & $0.0^{\mathrm{a}}$ & $0.0^{\mathrm{a}}$ & $0.0^{\mathrm{a}}$ & $0.0^{\mathrm{a}}$ & $0.0^{\mathrm{a}}$ & $0.0^{\mathrm{a}}$ & - & - & $0.0^{\mathrm{a}}$ & $0.0^{\mathrm{a}}$ & $0.0^{\mathrm{a}}$ & 0.0 \\
\hline
\end{tabular}

394 Means with the same alphabets across the row are not significantly different at $\mathrm{P}<0.05$ using Duncan Multiple Range Test (DMRT) for separation 395 of statistically significant means. Data collected were represented as “Means” only. Owódé-Igàngán (O-Igàngán), Qbáfémi-Owódé (Q-Owódé),

396 Dáagi-Lógbà (D-Lógbà) 


\section{Black pod disease intensity in Ondo, Ogun, Osun and Oyo States}

398 The level of black pod disease severity was milder in the early periods of the 2015/2016 cocoa

399 production season from the statutory disease assessment result documented in Table 11. It was

400 observed that the intensity of the disease was more in Osun state with mean disease severity of

$40130.0 \%$ in the month of May 2015 (during the rainy season), whereas, other states within the

402 Southwest had no signs or symptoms of the disease ( $0.0 \%$ BPD severity). The persistency of

403 black pod disease was more in June across cocoa farms located in Osun State (93.0\%) and Ondo

404 State $(76.7 \%)$. The intensity of black pod disease was relatively insignificant in other States

405 sampled within the same period.

406 There was rapid geometric increase in black pod disease expression and intensity within the 407 months of July and August with a climax in September 2015 (Table 11). The disease severity for 408 July was recorded thus: Ondo State (73.8\%), Osun State (70.1\%), Oyo State (76.7\%) and Ogun 409 State (0.0\%). In August, Ondo State recorded 92.9\% BPD intensity; Osun State had 84.6\%, 410 Ogun State (66.7\%) and Oyo State (75.0\%).

411 The disease intensity across Ogun, Ondo, Osun and Oyo States during the 2015/2016 cocoa 412 production season for September 2015 was 98.3\% (Ondo State), 86.7\% (Ogun State), 84.3\% 413 (Oyo State) and 77.9\% (Osun State). Ogun State had 100.0\% disease intensity in the month of 414 October 2015 which was contrary to the trend of disease progress in other States. Ondo State had $41527.5 \%$, Osun State (69.5\%) and Oyo State (0.0\%). Subsequently, other months within the dryer 416 periods of the year (2015/2016 cocoa production season) had insignificant disease intensity 417 values (0\%). The findings were recorded in Table 11. 
418 Table 11: An evaluation of the average level of black pod disease severity in some Southwestern

419 States

\begin{tabular}{lllll}
\hline & \multicolumn{3}{c}{ Black Pod Disease Severity (\%) } \\
\cline { 2 - 5 } Period & Ondo & Osun & Ogun & Oyo \\
\hline May, 2015 & $0.0^{\mathrm{b}}$ & $30.0^{\mathrm{a}}$ & $0.0^{\mathrm{b}}$ & - \\
June, 2015 & $76.7^{\mathrm{b}}$ & $93.0^{\mathrm{a}}$ & $0.0^{\mathrm{c}}$ & $76.7^{\mathrm{a}}$ \\
July, 2015 & $73.8^{\mathrm{b}}$ & $70.1^{\mathrm{c}}$ & $0.0^{\mathrm{d}}$ & $75.0^{\mathrm{c}}$ \\
Aug., 2015 & $92.9^{\mathrm{a}}$ & $84.6^{\mathrm{b}}$ & $66.7^{\mathrm{d}}$ & $84.3^{\mathrm{c}}$ \\
Sept., 2015 & $98.3^{\mathrm{a}}$ & $77.9^{\mathrm{d}}$ & $86.7^{\mathrm{b}}$ & $0.0^{\mathrm{d}}$ \\
Oct., 2015 & $27.5^{\mathrm{c}}$ & $69.5^{\mathrm{b}}$ & $100.0^{\mathrm{a}}$ & $0.0^{\mathrm{a}}$ \\
Nov., 2015 & $0.0^{\mathrm{a}}$ & $0.0^{\mathrm{a}}$ & $0.0^{\mathrm{a}}$ & $0.0^{\mathrm{a}}$ \\
Dec., 2015 & $0.0^{\mathrm{a}}$ & $0.0^{\mathrm{a}}$ & $0.0^{\mathrm{a}}$ & $0.0^{\mathrm{a}}$ \\
Jan., 2016 & $0.0^{\mathrm{a}}$ & $0.0^{\mathrm{a}}$ & $0.0^{\mathrm{a}}$ & $0.0^{\mathrm{a}}$ \\
Feb., 2016 & $0.0^{\mathrm{a}}$ & $0.0^{\mathrm{a}}$ & $0.0^{\mathrm{a}}$ & $0.0^{\mathrm{a}}$ \\
Mar., 2016 & $0.0^{\mathrm{a}}$ & $0.0^{\mathrm{a}}$ & $0.0^{\mathrm{a}}$ & $0.0^{\mathrm{a}}$ \\
April, 2016 & $0.0^{\mathrm{a}}$ & $0.0^{\mathrm{a}}$ & $0.0^{\mathrm{a}}$ & $0.0^{\mathrm{a}}$ \\
May, 2016 & $0.0^{\mathrm{a}}$ & $0.0^{\mathrm{a}}$ & $0.0^{\mathrm{a}}$ &
\end{tabular}

420 Means with the same alphabets across the row are not significantly different at $\mathrm{P}<0.05$ using

421 Duncan Multiple Range Test (DMRT) for separation of statistically significant means. Data

422 collected were represented as "Means" only

\section{Altitude and its effects on black pod disease expression}

424 It was observed that $15.0 \%$ black pod disease intensity was recorded for the month of May 2015

425 for cocoa farmlands located at altitude higher than $200 \mathrm{~m}$ above sea level $(201 \mathrm{~m}-300 \mathrm{~m})$ and $0.0 \%$

426 for cocoa plantations located within or below 200m above sea level (Table 12). The same trend

427 was observed in June 2015 with $84.8 \%$ black pod disease intensity for cocoa farmlands situated

428 within altitude $201 \mathrm{~m}-300 \mathrm{~m}$ and $0.0 \%$ for those located within or below $200 \mathrm{~m}$. 
429 BPD intensity was progressive through the months of July 2015 (38.4\% for cocoa farmlands

430 located below 200m altitude, and 71.9\% for cocoa plantations above 200m), August 2015

431 (70.9\% for cocoa fields below $200 \mathrm{~m}$ altitude, and $88.7 \%$ for areas above $200 \mathrm{~m}$ ), with its peak

432 value in September 2015 for cocoa farmlands located below 200m height above sea level (85.5\%

433 black pod disease expression), and $88.1 \%$ for areas above $200 \mathrm{~m}$ in altitude. There was a decline

434 in black pod disease expression in October 2015, with a recorded value of 50.0\% for areas

435 situated below or within $200 \mathrm{~m}$ height above sea level and $48.5 \%$ for areas above $200 \mathrm{~m}$. There

436 was no expression of the disease during the dry season (Table 12).

437 Table 12: The influence of altitude on black pod disease severity in Southwest Nigeria

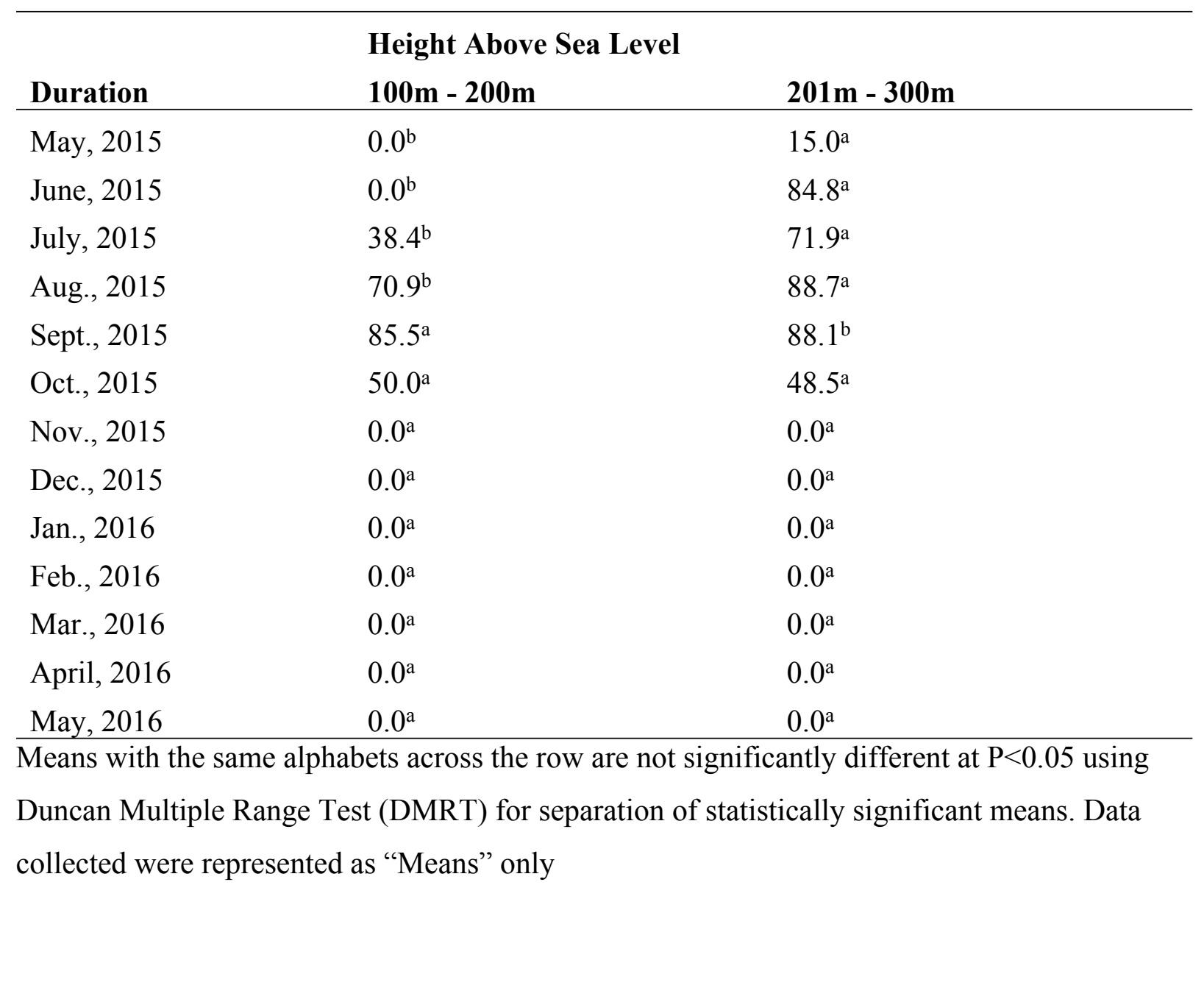




\section{Black pod disease diagnosis in Ogun, Ondo, Osun and Oyo States, Nigeria}

It was evident from the statutory disease assessment conducted that black pod disease was a major threat to cocoa production in Southwestern Nigeria. Its occurrence was recurrent and rapid with massive destruction and devastating effects as it spreads. Some areas identified to be under severe black pod disease attack include Òwenà and Wáàsimi in Ondo East local government area (LGA) of Ondo State, Adaàgbà and Iyánfowórogi in Ife South LGA of Osun State, Owódé-

451 Igàngán and its’ environs in Àtàkúnmòsà East LGA of Osun State, Qbáfémi-Owódé in Abeokuta integrated disease management strategies.

\section{7}

\section{The trend of black pod disease occurrence in Southwest, Nigeria}

458 It was noted that the severity of black pod disease, its prevalence and spread was widely 459 pronounced in the rainy season and there was $100 \%$ chances of black pod disease occurrence in 460 all the cocoa farmlands investigated as long as there was consistent pattern of rainfall within that 461 terrain. This was in agreement with the observations made by Adeniyi and Ogunsola [26] that the 462 yearly variation in the yield of cocoa is affected more by rainfall and the disease thrives better 463 when there is moisture available in the surrounding environment. Finally, the observations made 
in weather pattern which can greatly influence its yield and productivity, and predispose it to a greater extent to black pod disease infection.

Other findings accrued from the research conducted showed that black pod disease was the most influential among all the diseases limiting cocoa production in Southwest, Nigeria. It was also noticed that insects and pests attack on green and ripe cocoa pods occurred during the dry season at epidemic proportions. Akrofi [24] consented to this fact but he did not give any information on the season of occurrence of these pests. A combination of the multiple effects of the pests and diseases was a major threat to local cocoa farmers due to their high tendency to cause yield reduction, their fast spreading nature in the field and high devastating effects in terms of pod

474 destruction, depletion in quality nutrients of the bean, distortion of cocoa bean texture, colour and reduction of market values made it a major challenge for local cocoa growers within these terrain. A similar observation was also recorded by Flood co-workers [28].

\section{Black pod disease profile in the rural areas of Southwest, Nigeria}

478 Black pod disease was noticed early in "Owódé-Igàngán”, an area close to Ilèsà within 479 Àtàkúnmòsà East of Osun State and "Iyánfowórogi" located in Ife South (both in Osun State) in 480 the month of May, 2015; few months after the commencement of the rainy season. This was 481 indeed a reaffirmation of the statement made by Adisa and Adeloye [25] that Osun State has 482 been identified as a black pod disease prone region. Other research locations had no prevalence 483 of the disease. This was partly due to the fact that the environment was not favourable enough at 484 that point in time for the proliferation of black pod disease pathogen.

485 There was a change in the disease trend for the month of June 2015 as "Wáàsimi" (an area 486 located in the heart of Ondo State) had the highest black pod disease occurrence, closely 
487 followed by "Iyánfowórogi" in Ife South, "Òwenà (still in Ondo), and Adaàgbà (a village in

488 close proximity with "Iyánfowórogi " in Ife South of Osun State). Other locations like Ogun

489 State and Oyo State were black pod disease free. The same pattern of disease trend was

490 described by Opoku [3] in Ghana that the primary infections usually occur around June, but the

491 peak of black pod disease invasion generally occurs between August and October.

492 A similar pattern of disease spread was also observed for the month of July but in this case

493 “Òwenà and Wáàsimi had massive black pod disease incidence. Iyánfowórogi and Adaàgbà too

494 had substantial disease spread which was becoming a cause for worry to the local farmers.

495 Dáagi-Lógbà in Qnà-Arà local Government of Oyo State surprisingly joined the group of black

496 pod disease infected areas. This was still in concordance with previous findings [3, 7].

497 The pinnacle of infection was in August 2015 where the disease prevalence was at its peak,

498 unfortunately the same trend of black pod disease spread persisted, Òwenà and Wáàsimi (both

499 leading cocoa growing communities not just in the Southwest but in Nigeria at large) were at the

500 forefront of the disease predicament and as such the spotlight for research focus. Infected areas

501 like these with massive input in commercial cocoa production are regarded by epidemiologists as

502 the "area under disease curve" (AUDC). Farmlands in areas like Dáagi-Lógbà, Adaàgbà,

503 Iyánfowórogi and Qbáfémi-Owódé also had their fair share of infection. A similar observation

504 was also noted by Appiah [7] in the tropical regions of Ghana (where cocoa are widely

505 cultivated) that the height of $P$. megakarya induced black pod disease infection generally occurs

506 between August and October.

507 In September 2015, there was a change in disease preference with Adaàgbà taking the lead 508 trailed by Qbáfémi-Owódé, Dáagi-Lógbà, Wáàsimi, Òwenà, and Iyánfowórogi with the least 
509 level of black pod disease prevalence. There was a massive decline in disease outbreak in some

510 locations in the month of October like Dáagi-Lógbà, Wáàsimi and Òwenà, Iyánfowórogi and

511 Adaàgbà etc. Interestingly, Qbáfémi-Owódé showed a progressive geometric increase in black

512 pod diseases occurrence. The observations made from other locations (with the exception of

513 Qbáfémi-Owódé) were in contrast with the assertions given by Opoku [29] who noted that the

514 peak period for black pod disease invasion were between the months of August and October

515 where there is sufficient amount of surface water in the surrounding environment and high

516 pathological activities of the pathogen.

517 With the onset of the dry season, culminating in a drastic reduction in the top soil surface water,

518 reduced amount of rainfall, high ambient temperature, increased hours of sunshine (high

519 luminous potentials), decreased air saturation (low relative humidity) and due to the fact that

520 most cocoa farmers have harvested their pods from the farm, black pod disease occurrence for

521 the months of November and December 2015, likewise January, February, March, April and

522 May 2016 was drastically reduced to non-significant levels, and as such the disease posed no

523 threats to farmers during these period. This was in agreement with the reports given by Oluyole

524 and Lawal [30] who reiterated that black pod disease is prevalent only during the wet season.

\section{Black pod disease profile in Ogun, Ondo, Osun and Oyo States}

526 The statutory investigation of the average monthly black pod disease prevalence for Ondo, Ogun,

527 Osun and Oyo States was such that Osun State had a significant level of occurrence for the

528 month of May 2015 compared to other States with no recorded history or field reports for black

529 pod disease prevalence in May. Ondo and Osun States had a seemingly similar level of disease

530 prevalence, co-occupying the top position for black pod disease spread during the month of June 
531 2015, whereas there was no report of the disease in Ogun and Oyo States. This can be partly

532 explained by the similarity in weather pattern based on proximity in distance and agro-ecological

533 zoning of these States, a theme well described by Ziervogel [31] who stated that climate change

534 has wide-ranging effects on the environment including water resources, agriculture, food

535 security, human health, terrestrial ecosystems, biodiversity and coastal zones.

536 In July 2015, Ondo State had the highest level of black pod disease occurrence, seconded by

537 Osun State. Other States had little, insignificant or no disease prevalence at the point of

538 investigation. The preference for disease spread was uttered in the month of August 2015 with

539 Ondo State maintaining top position, subsequently followed by Oyo State. Osun State and Ogun

540 State just had minimal levels of black pod disease prevalence. Surprisingly, Ogun State had the

541 highest values for disease prevalence for the months of September and October 2015 during the

542 statutory disease assessment routine, followed by Oyo State, Osun State and lastly, Ondo State.

543 There was no occurrence of black pod disease in the dry season for all the cocoa farms

544 investigated in the course of this research. This was totally due to the fact that there was no

545 surface water to facilitate the proliferation and spread of the pathogen and most cocoa farmers

546 had harvested all their cocoa pods from the field. This was in agreement with the reports given

547 by Oluyole and Lawal [30] who reiterated that black pod disease is prevalent only during the

548 rainy season and that moisture is a pertinent factor for the development and spread of the disease.

549 Topography of cocoa farmland and its influence on black pod 550 disease development

551 It was learned in connection with this research that the establishment, spread and prevalence of 552 black pod disease on farmlands located in areas of high altitude $(>200 \mathrm{~m})$ had geometric increase 553 from the months of May through August 2015, followed by a rapid decline in the month of 
554 September and October. The aim of this assessment was to further determine the significance of

555 altitude in black pod disease development. Farmlands located in regions with lesser altitude

$556(<200 \mathrm{~m})$ had a slow start to black pod disease development with the pinnacle of black pod

557 disease spread in September 2015 and an abrupt decline in October 2015 through May 2016. A

558 cross comparison between the two height levels showed that the activities of the pathogen was

559 closely affected by the height above sea level of the environment and the rate of spread of the

560 disease was largely influenced to a great extent by the topography of the farmland.

\section{The intensity of black pod disease in Southwest Nigeria}

562 It was observed that the trend of black pod disease development and spread in Southwest,

563 Nigeria was logarithmical with a very slow start in the month of May 2015 and a gradual

564 increase through the months of June 2015, through July 2015 and August 2015 were the peak of

565 disease occurrence within the earmarked research locations were observed. A decline in black

566 pod disease value was observed in the month of September 2015, and further decline in disease

567 value occurred in October 2015 prior to harvesting of cocoa pods by farmers. The months of

568 November, December 2015, January, February, March, April and May 2016 had unsubstantial

569 amount of black disease severity.

570 The same trend of disease history was observed within this zone for the disease severity. The

571 zenith of disease intensity was in September 2015 and the least recorded degrees of black pod

572 disease intensity were for the months of November, December 2015, January, February, March,

573 April and May 2016 with insignificant disease intensity, which was largely due to the fact that

574 most farmers have harvested their cocoa pods and the Cherelles (young pods) which are still in

575 the juvenile stage were not the preferential target of Phytophthora megakarya. During these 
576 periods the farm environment was devoid of water which is a pertinent factor for the

577 proliferation of the organism (Phytophthoramegakarya) that caused black pod disease.

\section{The role of seasonal variation in black pod disease expression in 579 Southwest, Nigeria}

580 It was reported that Ondo State had the highest level of black pod disease prevalence (Incidence)

581 during the close of the year 2015 and Osun State had the highest level of disease Intensity

582 (Severity). These values were recorded during the rainy season. This was in agreement with the

583 research work of Akrofi [24] who reiterated that the survival and proliferation of Phytophthora

584 megakarya depends majorly on the availability of water most especially during the rainy season

585 where water is present in abundance in most cocoa farmlands around the African continent.

\section{A general assessment of the development and severity of black pod 587 disease in Southwest, Nigeria}

588 The overall annual disease occurrence observed within Southwest, Nigeria for the cocoa 589 production season ending 2016 were mildly severe while the levels of disease intensity on the 590 affected cocoa pods were moderately and extremely severe in some cases. The irregular black 591 pod disease management rate achieved around the investigated region was due to the fact that the

592 level of preparedness of the farmers within the affected region in terms of fungicide application 593 and good cultural practices to wade of potential agents of propagation and spread of the disease 594 differs greatly, partly due to ignorance and the level of information on the control of the disease 595 available to the local cocoa farmers and majorly due to financial constraints. This was in line 596 with the findings of the Cocoa Research Institute of Nigeria (2003). 


\section{Level of destruction of black pod disease in rural and sub-urban 598 community of Southwest, Nigeria}

599 The routine disease assessment conducted within twelve (12) selected rural and sub-urban

600 settlements in Nigeria reputed for cocoa farming in the Southwest showed that the level of black

601 pod disease intensity during the month of May 2015 was relatively high for "Owódé -Igàngán"

602 and "Iyánfowórogi" which were regarded as key cocoa production areas in Osun State. Other

603 locations across the Southwest of Nigeria had insignificant levels of black pod disease severity.

604 For the month of June 2015, "Wáàsimi”, "Iyánfowórogi”, “Òwenà etc. all had significant levels

605 of black pod disease severity, fascinatingly, Adaàgbà had the highest record of disease intensity

606 during this period. Other locations showed no signs of black pod disease severity.

607 The same pattern of disease severity was also observed for the month of July but in this case

608 Òwenà had the highest black pod disease incidence, with other sampled points like Wáàsimi,

609 Iyánfowórogi, Adaàgbà and Dáagi-Lógbà trailing closely behind. The pinnacle of black pod

610 disease severity was in September and not in August 2015 as conveyed in the earlier report of its

611 spread and prevalence. It was observed that a similar trend of disease severity occurred in August

612 within this zone, with Òwenà having a massive black pod disease infestation, Wáàsimi, Dáagi-

613 Lógbà, Adaàgbà, Iyánfowórogi and Qbáfémi-Owódé too had their fair share of black pod disease

614 infestation. This was described in pevious reports $[3,7]$.

615 In September 2015, there was a change in disease preference with Òwenà having the highest

616 mean recorded value for disease severity, Adaàgbà and other regions were reported to have

617 severe black pod disease intensity (Q̨áfémi-Owódé, Dáagi-Lógbà, Wáàsimi, and Iyánfowórogi).

618 There was a massive decline in disease severity in some locations in the month of October like

619 Dáagi-Lógbà, Wáàsimi, Òwenà, Iyánfowórogi and Adaàgbà, but surprisingly, Qbáfémi-Owódé 
620 showed a progressive geometric increase in black pod diseases intensity. The basic rationale

621 behind the heavy infestation by black pod disease was in the lack of disease management

622 strategy employed by the farmer. This confirms the assertion stated by Berry and Cilas [32] that

623 losses can reach up to $100 \%$ of the cocoa production in smallholders' plantations when no

624 control measures are taken.

625 With the onset of the dry season, culminating in a drastic reduction in the top soil surface water,

626 reduced amount of rainfall, high ambient temperature, increased hours of sunshine (high

627 luminous potentials), decreased air saturation (low relative humidity) and due to the fact that

628 most cocoa farmers have harvested their pods from the farm, black pod disease severity for the

629 months of November and December 2015, likewise January, February, March, April and May

6302016 was drastically reduced to non-significant levels, and as such the disease posed no threats

631 to farmers during these periods. This was in line with the assertion made by Ziervogel et al. [31].

\section{Black pod disease intensity in Ogun, Ondo, Osun and Oyo States}

633 It was observed that black pod disease started very early in cocoa farmlands located in Osun state

634 in the month of May 2015 during the rainy season. Osun State still led the chart for high ranking

635 black pod disease severity in the southwest for the month of June 2015, followed by Ondo State.

636 Other States had insignificant disease history for the month of June 2015. There was rapid

637 geometric increase in black pod disease expression and intensity within the months of July and

638 August with a climax in September 2015 for Ondo State, Osun State, Oyo State and Ogun State.

639 The same sequence for disease prevalence was earlier given by Appiah [7]. Other preceding 640 months had insignificant disease intensity status. 


\section{Landscape and black pod disease expression on cocoa pods in}

642 Nigeria

643 There was disease infestation recorded for cocoa farmlands located within areas situated in

644 altitude higher than $200 \mathrm{~m}$ above sea level $(201 \mathrm{~m}-300 \mathrm{~m})$ and none for areas located below $200 \mathrm{~m}$

645 above sea level in the month of May 2015. The same trend was observed in June 2015. The

646 disease intensity trend was progressive through the months of July 2015 and August, with its

647 peak value in September 2015 for cocoa farmlands located in areas situated below 200m height

648 above sea level, follow by retrogression in disease intensity value in October 2015, through the

649 dry season. This was as suggested by Appiah [7].

\section{Supporting information}

\section{S1 Appendix: Details of study sites}

652 S1 Fig: A semi-biased mode of disease sampling within an earmarked cocoa field ( $\mathrm{T}$ - Cocoa 653 tree)

\section{Conclusion}

655 It was established by the research conducted that black pod disease was and still is a major threat

656 to cocoa farmers in Southwest, Nigeria. Farmers within the rural communities are indeed tired of

657 the huge loss incurred from the spread of the disease due to the recurrent and devastating effects

658 of the disease, cocoa farming is fast becoming a myth in this region. Unless concerted efforts

659 towards black pod disease management is put in place, cocoa farming will go into extinction in

660 Nigeria. 
1. FAOSTAT; 2018 [cited 2018 Nov 12]. Database available from: http://www.fao.org/faostat/en/\#data/RFN 43.

3. Opoku IY, Appiah AA, Akrofi AY, Owusu GK. Phytophthora megakarya: a potential threat to the cocoa industry in Ghana. Ghana J Agric Sci. 2000;33(2):237-48.

4. Thorold CA. Diseases of cocoa. Clarendon Press.; 1975.

5. Dakwa JT. A serious outbreak of black pod disease in a marginal area of Ghana. InProceedings of the 10th international cocoa research conference 1987 May 17 (pp. 447451). identification of cacao black pod causal agents and identification of biological factors possibly contributing to Phytophthora megakarya's field dominance in West Africa. Plant Pathol. 2016 Sep;65(7):1095-108. Pathol. 2004 Dec 1;110(10):983-90. University of Missouri Agricultural Experiment Station 1931;53:208. Soc. $1969 ; 52: 425-36$. 
11. Sreenivasan TN. A new Phytophthora. Annual Report, Cacao Research Unit, St.

686

687

688

689

690

691

692

693

694

695

696

697

698

699

700

701

702

703

704

705

706

707

708

Augustine, Trinidad, 1975.20pg.

12. Kaosiri T. Morphological, taxonomical and cytological studies of Phytophthora palmivora. PhD dissertation, University of California, Riverside 1978. 148pg

13. Brasier CM, Griffin MJ. Taxonomy of 'Phytophthora palmivora' on cocoa. Trans Brit Mycol Soc. 1979;72(1):111-43.

14. Kellam MJ, Zentmyer GA. Isolation of Phytophthora citrophthora from cacao in Brazil, Phytopathol. 1981;71:230.

15. Liyanage NIS, Wheeler BEJ. Phytophthora katsurae from cocoa. J Plant Pathol 1989;38: 627-29.

16. Aragaki M, Uchida JY. Morphological distinctions between Phytophthora capsici and $P$. tropicalis sp. Mycologia 2001;93:137-45

17. Bowers JH, Bailey BA, Hebbar PK, Sanogo S, Lumsden R.D. The impact of plant diseases on world chocolate production. Plant Health Proramme 2001;3(1):13-16

18. Erwin DC, Ribeiro OK. Phytophthora Diseases Worldwide. Am Phytopathol Soc. $1996 ; 4(2): 8-12$

19. Chakraborty S, Tiedemann AV, Teng PS. Climate Change: Potential impact on plant diseases. Elsevier J Env Poll. 2000;108: 317-26

20. Zentmyer GA. Taxonomic relationships and distribution of species of Phytophthora causing black pod of cocoa. Proceedings of the Tenth International Cocoa Research Conference, Santo Domingo, Dominican Republic, 17-23 May 1987. London, UK: Cocoa Producers' Alliance, 391-395.

21. Agbeniyi SO, Adedeji AR. Current Status of Blackpod Epidemics in Nigeria. InProceedings of 14th International Cocoa Research Conference 2003 (pp. 1377-1380). 

regression (Doctoral dissertation, University of Leeds (Department of Statistics)). in Nigeria: Cocoa Research Institute of Nigeria (crin) as a case study. InAfrican Crop Science Conference Proceedings 2007 (Vol. 8, pp. 423-426). West Africa. Afr Crop Sci J. 2015;23(1):67-87.

25. Adisa BO, Adeloye KA. Analysis of farmer field school as an extension approach to cocoa production in Osun State, Nigeria. World J Agric Sci 2012;8(4):421-8. factors: A case study of Ayedire local government area of Osun State, Nigeria. Agric Sci. $2014 ; 2(4): 1-3$. of climate change on cocoa production. Accra, Ghana. 2005.

28. Flood J, Murphy R. Cocoa futures: A source book of some important issues facing the cocoa industry. Federación de Cafetaleros de Colombia, Chinchiná (Colombia) CABI,

30. Oluyole KA, Lawal JO. Determinants of the occurrence of black pod disease of cocoa in Edo State, Nigeria: A multivariate probit analysis approach. J. Innov Dev Strat. $2008 ; 2(2): 1-4$. 

and change: Implications for household food security. Assessment of Impacts and Adaptations to Climate Change (AIACC): Washington, DC, USA. 2006 Jan. 


\section{Black Pod Disease Occurrence in Southwest, Nigeria}

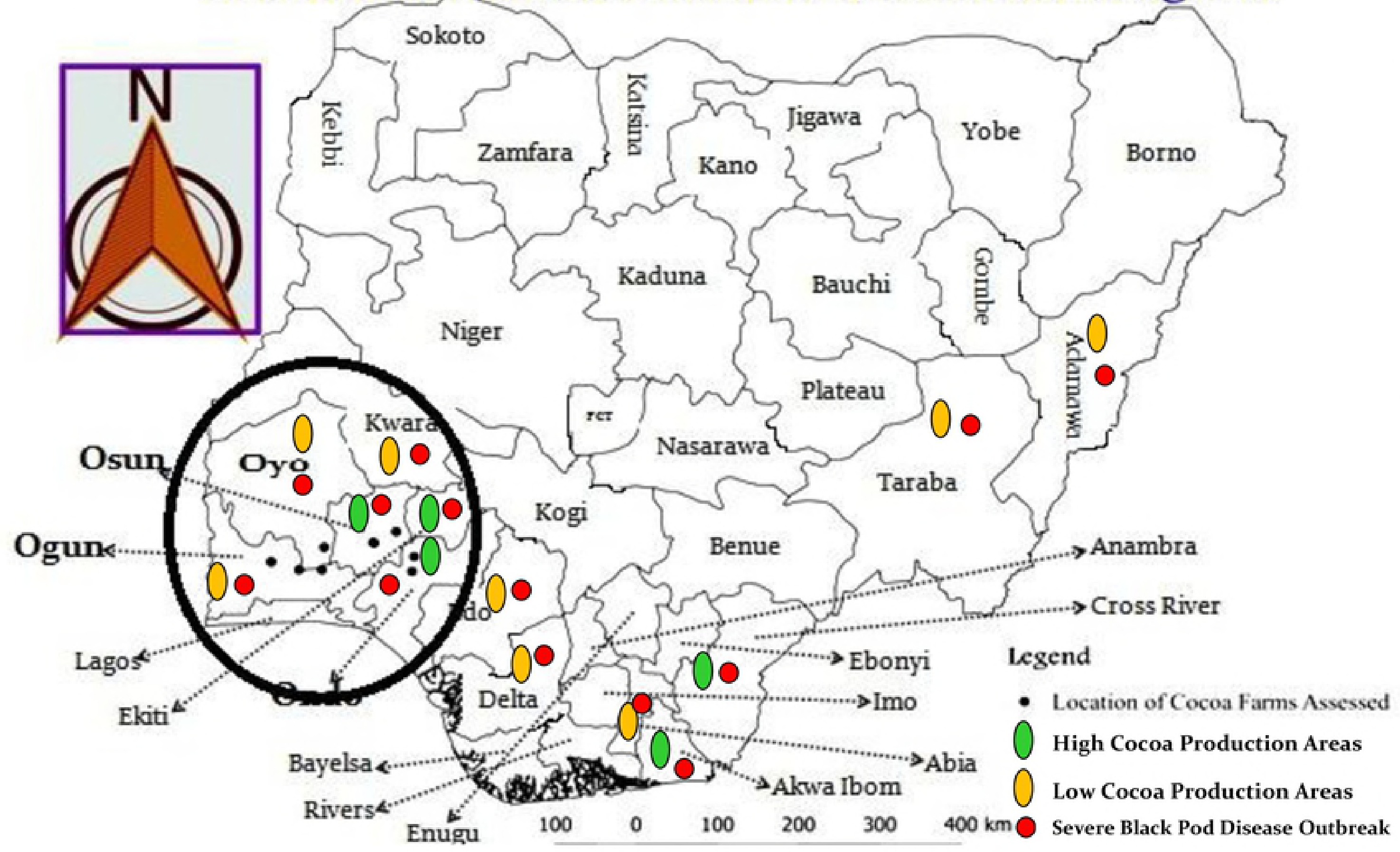

Fig 2 


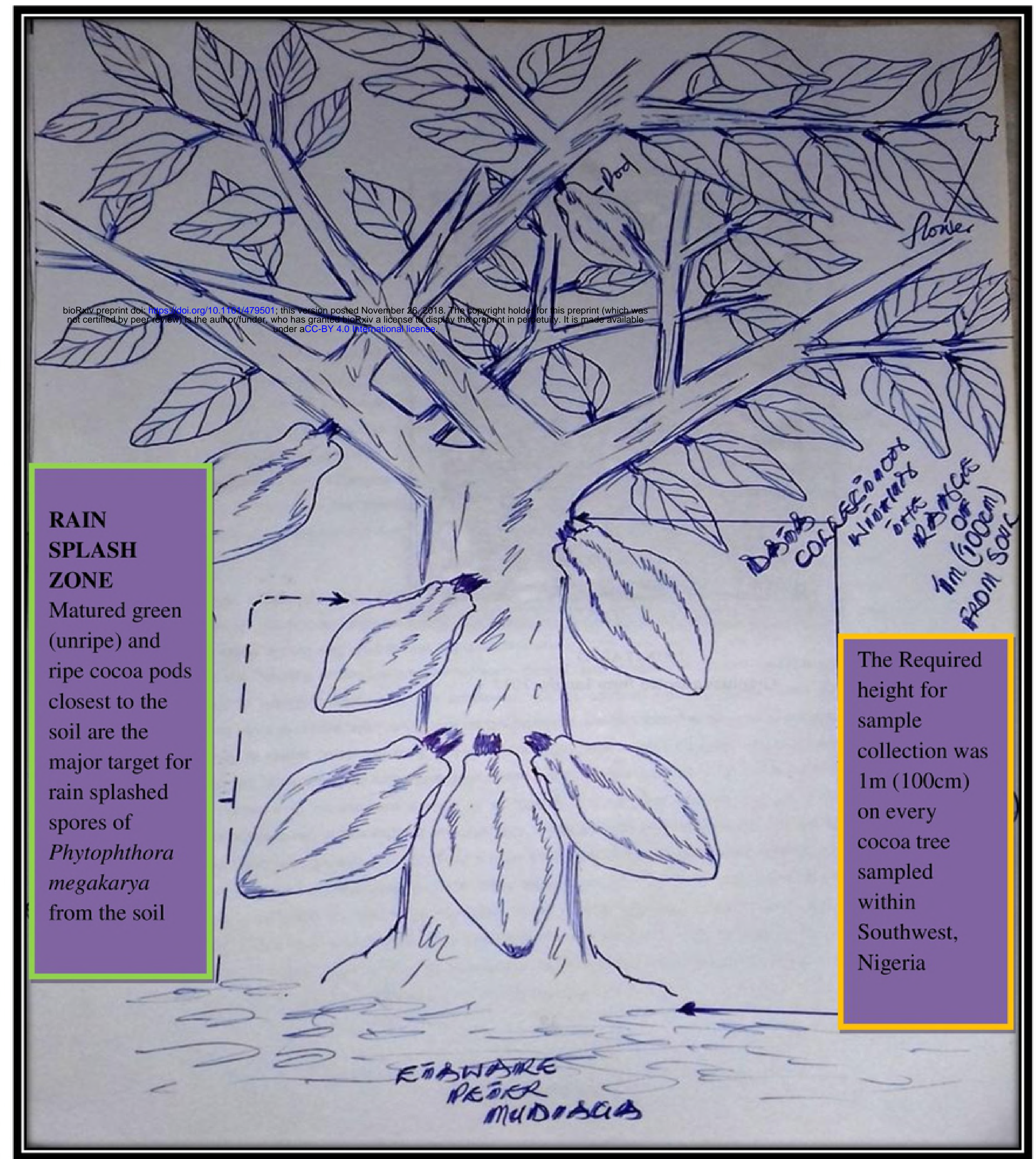

Fig 3 
Orientation of the mycelia of

Phytophthora megakarya on PDA

A

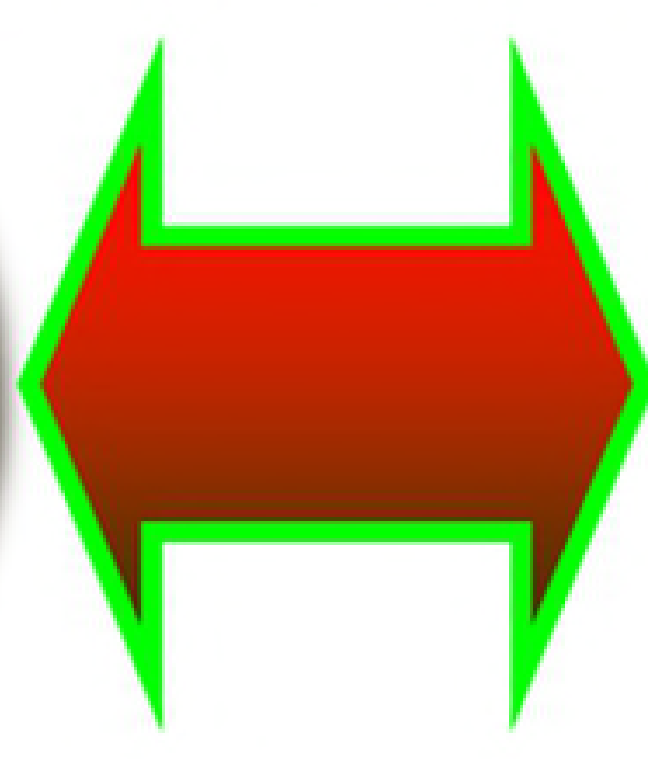

Photomicrograph of

Fig 4 


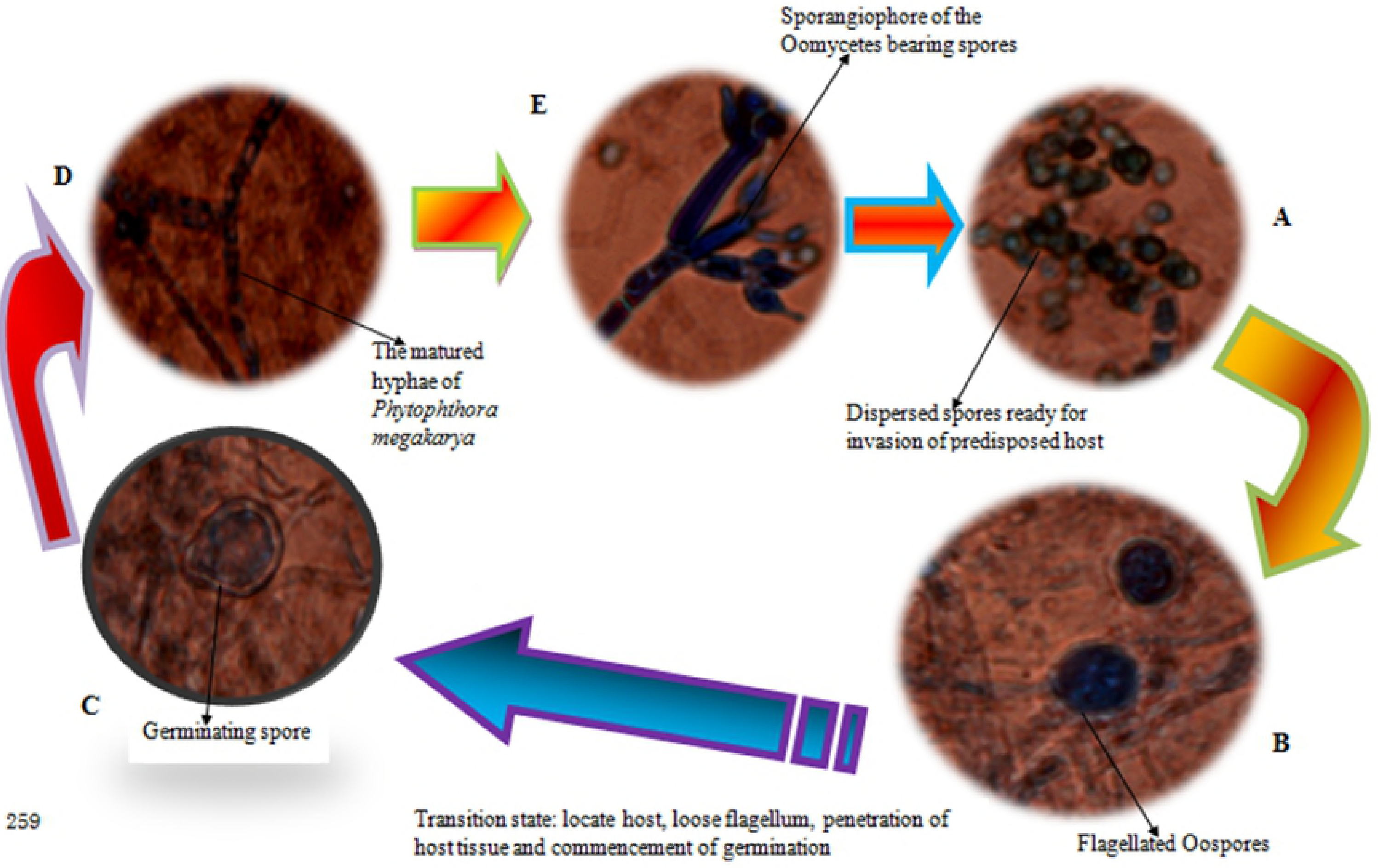

Fig 5 
